\title{
EFFECT OF EPOXIDIZED NATURAL RUBBER AS A COMPATIBILIZER IN SILICA-FILLED STYRENE BUTADIENE RUBBER COMPOUND
}

\author{
Indra Surya, Siswarni MZ \\ Department of Chemical Engineering, Engineering Faculty, University of Sumatera Utara, \\ Medan 20155, Indonesia \\ Email : indradanas@yahoo.com
}

\begin{abstract}
Abstrak
Dengan menggunakan sistim vulkanisasi semi-effisien, pengaruh Karet Alam Terepoksida (KAT) sebagai bahan penyerasi bagi kompon Karet Stirena Butadiena (KSB) berpengisi silika diamati. KAT ditambahkan ke dalam kompon KSB berpengisi silika dengan kadar 5.0 dan 10.0 bagian per-seratus bagian KSB (bsk). Pengamatan dilakukan dngan mengamati pengaruh KAT terhadap karakteristik pematangan dan sifat-sifat uji tarik dari KSB berpengisi silika. Teramati bahwa KAT mengakibatkan peningkatan laju pematangan bagi KSB berpengisi silika. KAT juga mengakibatkan peningkatan perbedaan tork, modulus tarik, dan kekuatan tarik hingga penambahan KAT mencapai 10.0 bsk. Studi terhadap interaksi antara karet dengan pengisi, menunjukkan bahwa penambahan KAT ke dalam KSB berpengisi silika mengakibatkan peningkatan interaksi antara KSB dengan pengisi silika.
\end{abstract}

Kata kunci : karet alam terepoksida; karet stirena butadiena; vulkanisasi; interaksi karet - pengisi; sifatsifat uji tarik.

\begin{abstract}
By using a semi-efficient vulcanization system, the effect of Epoxidized Natural Rubber (ENR) as a compatibilizer in silica-filled Styrene Butadiene Rubber (SBR) compound was carried out. The ENR was incorporated into the silica-filled SBR compound at 5.0 and $10.0 \mathrm{phr}$. An investigation was carried out to examine the effect of ENR on cure characteristics and tensile properties of the silica-filled SBR compound. It was found that ENR gave enhanced cure rate to the silica-filled SBR compound. ENR also exhibited a higher torque difference, tensile modulus, and tensile strength up to $10.0 \mathrm{phr}$. The study of rubber - filler interaction proved that the addition of ENR to the silica-filled SBR system improved the rubber - filler interaction.
\end{abstract}

Keywords : epoxidized natural rubber; styrene butadiene rubber; vulcanization; rubber - filler interaction; tensile properties.

\section{Introduction}

Besides carbon blacks, silicas of varying forms and particles-sizes have been widely used as reinforcing fillers in rubber industry. In general, the properties of silica-reinforced rubbers are usually inferior to those of carbon blacks, even when they are of comparable size [11]. This is attributed to apparent dissimilarity of surface chemistry of both of them. Carbon black will react with sulfur during vulcanization and form sulfur bonds that link the rubber chains also tie the carbon black on the rubber. This is filler - rubber crosslinking, another type of crosslink to rubber system, and defined as coupling bonds [6-7]. In marked contrast to the hydrocarbon functionality of carbon black, silica does not react with sulfur, and due to its hydrophilic silanol groups that are relatively incompatible with hydrocarbon rubbers, such as Natural Rubber (NR), and Styrene Butadiene Rubber (SBR), thus, coupling bonds will not be formed.

For many applications, silicas are not satisfactory alternatives to carbon blacks, because of inadequate reinforcement levels. The fundamental problem is their surface characteristics which are more polar and hydrated than carbon black, and which cause then to be difficult to wet, disperse and interact with hydrocarbon rubbers. Numerous technologies have been done to improve reactivity of silica with the rubber phases. One of them is the utilizing of silane-coupling agent. The coupling agent modifies the surface of silicas. The modified silicas provide chemically active surfaces that can participate in vulcanization, providing coupling bonds between silane and both the silicas and the rubber phases [8-9]. Those products show significant improvement in performance compared to its base material.

An alternative method to overcome the deficiency of silica is the utilization of Epoxidized Natural Rubber (ENR). The ingredient is a product of chemical modification on NR. This article describes the utilization of ENR as a compatibilizer in silica-filled SBR compound. 


\section{Experimental \\ Materials}

Epoxidized Natural Rubber with $50 \%$ mole of epoxidation (ENR 50) was used. Other compounding ingredients were sulphur, zinc oxide, stearic acid, N-isopropyl-N'-phenyl-pphenylenediamine (IPPD), N-sikloheksil-2-benzol tiazolsulfenamide (CBS), Precipitated Silica, and SBR.

\section{Compounding}

A semi efficient vulcanization system was used for compounding. The recipe for the preparation of the SBR compound is given in Table 1. Table 2 displayed the compound designation and composition of the SBR-based recipes. The compounding procedure was done in accordance with the American Society for Testing and Material (ASTM) - Designation D 3184 - 80. Compounding was done on two-roll mill.

\section{Table 1. Composition of the rubber compounds}

\begin{tabular}{|l|l|}
\hline Ingredients & Content $(\mathrm{phr})^{*}$ \\
\hline SBR & 100.0 \\
ENR 50 & $0.0 ; 5.0 ;$ and 10.0 \\
Precipitated silica & 30.0 \\
(Vulcasil S) & \\
Sulphur & 1.5 \\
Zinc oxide & 5.0 \\
IPPD & 2.0 \\
Stearic acid & 2.0 \\
CBS & 1.5 \\
\hline
\end{tabular}

parts per hundred parts of rubber

Table 2. Designation and Composition of the SBR-based recipes

\begin{tabular}{|c|c|c|}
\hline Designation & Composition & $\begin{array}{c}\text { SBR/ENR } \\
\text { 50/Silica } \\
\text { (phr) }\end{array}$ \\
\hline $100 / 0 / 0$ & Gum/unfilled SBR & $100 / 0 / 0$ \\
\hline $100 / 0 / 30$ & $\begin{array}{l}\text { Silica-filled SBR } \\
\text { without ENR } 50\end{array}$ & $100 / 0 / 30$ \\
\hline $95 / 5 / 30$ & $\begin{array}{l}\text { Silica-filled SBR } \\
\text { with ENR } 50\end{array}$ & $95 / 5 / 30$ \\
\hline $90 / 10 / 30$ & $\begin{array}{l}\text { Silica-filled SBR } \\
\text { with ENR } 50\end{array}$ & $90 / 10 / 30$ \\
\hline
\end{tabular}

\section{Cure Characteristics}

The cure characteristics of the CB-filled NR compounds were obtained using a Monsanto Moving Die Rheometer (MDR 2000), which was employed to determine the scorch time $\left(\mathrm{ts}_{2}\right)$, cure time $\left(t_{90}\right)$ and torque difference $\left(\mathrm{M}_{\mathrm{H}}-\mathrm{M}_{\mathrm{L}}\right)$, according to ISO 3417. Samples of the respective compounds were tested at $150^{\circ} \mathrm{C}$. The compounds were subsequently compression-moulded using a stainless steel mould at $150^{\circ} \mathrm{C}$, with a pressure of $10 \mathrm{MPa}$, and applying a laboratory hot-press based on respective curing times.

\section{Tensile Properties}

Dumbbell-shaped samples were cut from the moulded sheets. Tensile tests were performed at a cross-head speed of $500 \mathrm{~mm} / \mathrm{min}$ using an Instron 3366 universal tensile machine, according to ISO 37. The tensile strength (TS), stress at $100 \%$ elongation (M100), stress at $300 \%$ elongation (M300) and elongation at break (EB) were determined.

\section{Measurement of Rubber - filler Interaction}

The rubber-filler interaction was determined by swelling the cured CB-filled NR compounds in toluene, according to ISO 1817. Test pieces with dimensions of $30 \mathrm{~mm} \times 5 \mathrm{~mm} \times 2 \mathrm{~mm}$ were prepared from the moulded sheets. The initial weights were recorded prior to testing. The test pieces were then immersed in toluene and conditioned under room temperature in a dark environment for 72 hours. After the conditioning period, the weights of the swollen test pieces were recorded. The swollen test pieces were then dried in the oven at $70^{\circ} \mathrm{C}$ for 15 minutes and were allowed to cool at room temperature for another 15 minutes before the final weights were recorded. The Lorenz and Park's equation [10] was applied in this study. The swelling index was calculated according to Equation (1).

$\mathrm{Qf} / \mathrm{Qg}=\mathrm{ae}^{-\mathrm{z}}+\mathrm{b}$

Whereby, the subscripts $\mathrm{f}$ and $\mathrm{g}$ referred to filled and gum vulcanisates, respectively; $\mathrm{z}$ was the ratio by weight of filler to hydrocarbon rubber in the vulcanisate; while $a$ and $b$ were constants. The higher the Qf/Qg value, the weaker the rubber-filler interaction became.

In this study, the weight of the toluene uptake per gram of hydrocarbon rubber $(\mathrm{Q})$ was calculated based on Equation (2).

$\mathrm{Q}=[$ Swollen - Dried weight $] /[$ Initial weight $\mathrm{x}$ 100/Formula weight]

\section{Results and Discussion The effect of ENR on Curing Behavior}

The effect of ENR on scorch and cure times of silica-filled SBR compound is shown in Table 3. It can be observed that scorch and cure times decreased with increasing the ENR loading. The addition of ENR up to $10.0 \mathrm{phr}$ caused in a higher value of (Tmax - Tmin). This phenomenon can be attributed to the enhancement of reinforcing effect of silica, a better silica dispersion, and the formation of additional physical crosslinks by silica - SBR attachments [12]. These physical crosslinks, together with sulfide crosslinks, contribute to total crosslink density [2-5]. The total crosslink density can be measured relatively by the difference between the maximum torque and minimum torque values [1-4]. 
Table 3. Curing Characteristics of Unfilled and Silica-filled SBR Compounds

\begin{tabular}{|c|c|c|c|c|}
\hline SBR-based compound & $100 / 0 / 0$ & $100 / 0 / 30$ & $95 / 5 / 30$ & $90 / 5 / 30 /$ \\
Cure characteristics & & & & 9.39 \\
\hline Scorch time/ts ${ }_{2}$, min. & 9.28 & 11.66 & 10.33 & 22.74 \\
Cure time/ $t_{90}$, min & 13.32 & 25.45 & 14.98 & 15.41 \\
Tork max., dN.m & 6.18 & 15.16 & 2.43 & 2.56 \\
Tork min., dN.m & 0.72 & 2.67 & 12.55 & 12.85 \\
Tork difference, dN.m & 5.46 & 12.49 & & \\
\hline
\end{tabular}

Table 4. The Effect of ENR Loading on Tensile Properties of Silica-filled SBR Vulcanizates

\begin{tabular}{|c|c|c|c|c|}
\hline SBR Vulcanizates & $100 / 0 / 0$ & $100 / 0 / 30$ & $95 / 5 / 30$ & $90 / 10 / 30$ \\
Tensile Properties & & & & \\
\hline M100, MPa & 0.70 & 1.31 & 1.34 & 1.36 \\
M300, MPa & 1.20 & 2.21 & 2.82 & 3.04 \\
TS, MPa & 1.52 & 12.33 & 13.18 & 16.23 \\
EB, \% & 374.3 & 987.0 & 939.0 & 844.7 \\
\hline
\end{tabular}

The effect of ALK on Rubber - filler Interaction

The rubber - filler interaction depends on the degree of the filler dispersion in the rubber phase. The better the filler dispersion, the stronger will be the rubber - filler interaction. The rubber filler interaction due to the addition of ALK into the CB-filled compound, based on the Lorenz and Park's equation, is presented in Fig. 1.

It can be seen that, the $\mathrm{Qf} / \mathrm{Qg}$ value decreased with increasing the ENR loading. The decrease in Qf/Qg value indicates that the SBR silica interaction became stronger due to the addition of ENR into the silica-filled SBR compound. This can be attributed to the ability of ENR as a compatibilizer to the silica-filled SBR system, and consequently improved the SBR silica interaction.

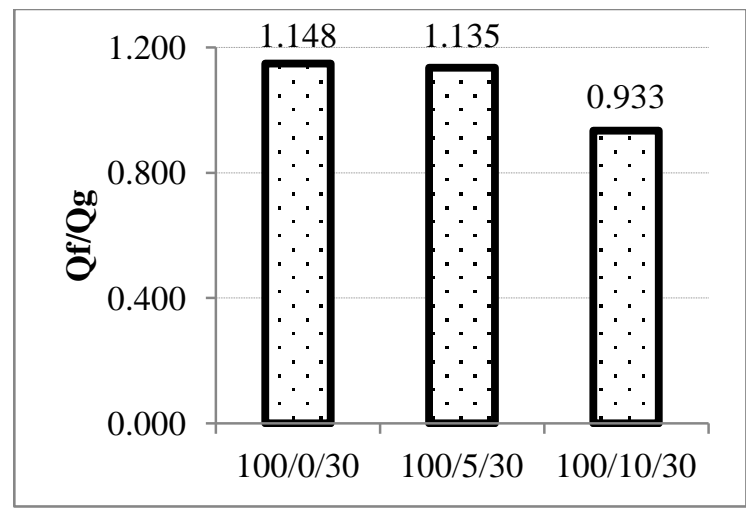

Figure 1. Qf/Qg values of the Silica-filled SBR vulcanizates at various ENR loadings

\section{The effect of ENR on Tensile Properties}

The effect of ENR loading on tensile properties of silica-filled SBR vulcanizates is shown in Table 4. It can be seen that M100 and M300 increased slightly up to maximum level (10.0 phr). The result of tensile strength also exhibits similar trend. The enhancement in tensile modulus and tensile strength, up to $10.0 \mathrm{phr}$ ALK loading, is attributed to the improvement of the rubber-filler interaction due to the incorporation of ENR.

\section{Conclusions}

Epoxidized Natural Rubber can be utilized as a compatibilizer in silica reinforcement of Styrene Butadiene Rubber. The incorporation of Epoxidized Natural Rubber into silica-filled Styrene Butadiene Rubber compound enhances cure rate, and reduce scorch time. Results also indicate that Epoxidized Natural Rubber improved the rubber-filler interaction in the silica filled Styrene Butadiene Rubber compounds. The incorporation of Epoxidized Natural Rubber also enhanced the rubber-filler interaction and tensile properties of the silica-filled Styrene Butadiene Rubber vulcanizate especially up to $10.0 \mathrm{phr}$ of loading.

\section{Acknowledgements}

The authors would like to thank Directorate General of Higher Education Ministry of Education and Culture of Republic Indonesia for Research Grant, under Penelitian Fundamental scheme, with Contract No. 4268/UN5.1.R/KEU/ 2013. 


\section{References}

[1] B. Boonstra, H. Cochrane, E. Dannenberg, Reinforcement of silicone rubber by particulate silica, Rubber Chemistry and Technology, 48 (1975) 558-576.

[2] G. Kraus, Reinforcement of elastomers, John Wiley \& Sons Inc, 1965.

[3] H. Cochrane, C. Lin, The influence of fumed silica properties on the processing, curing, and reinforcement properties of silicone rubber, Rubber Chemistry and Technology, 66 (1993) 48-60.

[4] H. Ismail, C. Ng, Palm oil fatty acid additives (POFA's): Preparation and application, Journal of elastomers and plastics, 30 (1998) 308-327.

[5] K. Polmanteer, C. Lentz, Reinforcement studies-effect of silica structure on properties and crosslink density, Rubber Chemistry and Technology, 48 (1975) 795-809.

[6] M. Fetterman, Precipitated Silica--Coming of Age, Rubber World, 194 (1986) 38-40.

[7] M.Q. Fetterman, The unique properties of precipitated silica in the design of high performance rubber, Elastomerics, 116 (1984) 18-31.

[8] M. Ranney, C. Pagano, Silane coupling agent effects in ethylene propylene diene terpolymers, Rubber chemistry and Technology, 44 (1971) 1080-1092.

[9] M. Wagner, Heat Generation and RubberFiller Coupling Bonds, Rubber Chemistry and Technology, 47 (1974) 697-716.

[10] O. Lorenz, C. Parks, The crosslinking efficiency of some vulcanizing agents in natural rubber, Journal of Polymer Science, 50 (1961) 299-312.

[11] P.E. Pinter, and Mc. Gill, C.R., , Comparing rubber fillers in an energy conscious economy, Rubber World International, 177 (1978) 3037.

[12] R. Nunes, J. Fonseca, M. Pereira, Polymerfiller interactions and mechanical properties of a polyurethane elastomer, Polymer testing, 19 (2000) 93-103. 